\title{
Construction of Accounting Curriculum System Based on the Theory of Integrating Specialty and Innovation
}

\author{
Wang Jue, Wang Jianhua \\ School of Economic and Management, Xl'AN University, Xi'an, China
}

Keywords: Accounting major, Innovation and entrepreneurship education, Integration of specialty and innovation

\begin{abstract}
Integration of specialty and innovation is an important part of deepening the reform of innovation and entrepreneurship education in China. Based on this theory, this paper divided accounting education into basic stage, specialized stage and comprehensive stage, constructed the curriculum system of accounting major at the levels of theory and practice, proposed to integrate the theme elements of innovation and entrepreneurship into the teaching of core curricula, highlighted the innovation ability training, accelerated the informatization construction of high-quality curricula in accounting education, and combined the curriculum reform to develop distinctive model courses integrating specialty and innovation.
\end{abstract}

\section{Introduction}

The reform of innovation and entrepreneurship education in colleges and universities is the need to promote the comprehensive reform of higher education and implement the national innovation-driven development strategy. In 2010, the Ministry of Education proposed to vigorously promote innovation and entrepreneurship education in higher education institutions, actively encourage college students to start their own businesses and promoted full employment. In 2015, The State Council proposed nine major tasks and measures for deepening the reform implementation of innovation and entrepreneurship education in institutions of higher education, and put forward clear requirements for strengthening innovation and entrepreneurship education. In 2018, the Ministry of Education issued a notice on deepening the construction of model universities for the reform of innovation and entrepreneurship education, deeply promoting the reform of innovation and entrepreneurship education at a higher level, deeper degree and more critical link, and proposed that innovation and entrepreneurship education should be closely connected with professional education and deeply integrated into the whole process of talent cultivation.

\section{Educational theory of integrating specialty and innovation}

Integration of specialty and innovation, which means to closely combine innovation and entrepreneurship education with professional education, serves as an important part of deepening the reform of innovation and entrepreneurship education in China and building an upgraded version of the "Five Education Platforms" for innovation and entrepreneurship education. Innovation and entrepreneurship education should be oriented to all students and integrated into the whole process of talent cultivation, to promote the close integration of innovation and entrepreneurship education with ideological and political education, professional education, and physical, aesthetic and labor education, which is a new requirement for deepening the reform of innovation and entrepreneurship education. Integrate innovation and entrepreneurship education into professional education, cultivate innovation awareness and spirit, guide students to make full use of professional knowledge, understand the characteristics of the market and industry, master the business operation model and basic knowledge of business management, formulate business development strategy, prevent and control risks, operate independently, start a business and obtain employment.

In June 2004, the American Entrepreneurship Education Association proposed that entrepreneurship education should be carried out throughout the lifelong learning process, and formulated national standards for entrepreneurship education, including three categories of 
entrepreneurial ability, preparatory ability and business function and 15 basic subject requirements. Among them, the standards of business foundation, digitization ability, financial knowledge, financial literacy, financial management, information management, operation management, risk management, strategic management, professional development and planning are all closely related to the objectives of accounting talent cultivation. It is necessary to promote the coordinated development of innovation and entrepreneurship education and professional education, integrate innovation and entrepreneurship education into professional education and the accounting talents training program, focusing on the adjustment and improvement of the accounting curriculum system, teaching objectives and teaching methods, so that innovation and entrepreneurship education can be organically integrated and connected with the specialized curricula of accounting and practical teaching.

\section{The status quo of the implementation of innovation and entrepreneurship education in the cultivation of accounting talents}

At present, in the accounting talent training program, colleges and universities generally offer general courses such as Entrepreneurship Foundation, Entrepreneurship, and Career Development and Employment and Entrepreneurship Education, which mainly involve innovation of thinking mode, business plan, organizational construction and enterprise management. Due to the limitations of class hours, the introduction of knowledge about corporate financial management is not comprehensive and systematic, while the accounting major involves courses of financial budget, financial accounting, cost control, financial analysis, business decision making, risk control, performance assessment, etc., which plays an important role in cultivation of innovative thinking and the improvement of entrepreneurial management ability. However, in the current talent training process, there are still problems such as insufficient understanding of the spirit of innovation and entrepreneurship education reform, not enough attention, the idea of innovation and entrepreneurship education lagging behind, not tight combination with professional education, unsound curriculum system, and limited faculty. From teaching content to the construction of teaching materials, the teaching of accounting curricula belongs to the traditional teaching system structure, mainly for industrial enterprises, without directing at scientific and technological enterprises and small microservice industries with many innovative and entrepreneurial college students. The professional education is not combined with innovation and entrepreneurship. The professional education and the innovation and entrepreneurship education have become two systems and do not blend well, which is inconsistent with the Ministry of Education's education theory of integrating specialty and innovation.

\section{Construction of accounting curriculum system integrating specialty and innovation}

In the innovation and entrepreneurship education, it is very important to master the specialized knowledge of economics and management, especially of accounting. The financial activities of modern enterprises mainly consider the management factors such as the model of corporate value creation, the organizational structure, business operation and management model, and information system establishment. Especially, in the era of data technology revolution, the emergence of the technical means such as big data, intellectualization, financial cloud, etc., has changed the mode of traditional accounting and forced the transition from financial accounting to management accounting. The focus of accounting specialized education has shifted to strategic management, budget management, cost management, internal control and risk management, and performance management. Combined with the basic requirements of accounting development and innovation and entrepreneurship education, the construction of accounting curriculum system can be divided into two levels (the theoretical level, the practical level) and three stages (basic stage, specialized stage, and comprehensive stage). 


\subsection{In the basic stage, students learn basic knowledge and basic skills}

At the theoretical level, courses of career planning, entrepreneurship foundation, economics, management, accounting, statistics, economic law, marketing, introductionto e-commerce, computer technology, and electronic payment are set; At the practice level, social practice, market research, case study of innovation and entrepreneurship, comprehensive simulation training of accounting are carried out.

\subsection{In the specialized stage, students learn business management expertise and perform innovation and entrepreneurship training}

At the theoretical level, courses of financial management, cost and management accounting, budget management, strategic management, performance management, internal control and risk management, tax planning, business data analysis, market research and forecasting are offered; At the practice level, venture capital project training, accounting computerization, e-commerce training, entrepreneurial planning, entrepreneurial competitions, accounting skills competitions, and professional internships, etc. are implemented.

\subsection{In the comprehensive stage, students learn and practice comprehensive and expanded knowledge}

At the theoretical level, courses of financial report analysis, international trade, finance, business communication and negotiation, e-commerce project management, supply chain and logistics management, public relations, and public relations etiquette are set; At the practice level, ERP business operation of sand table simulation, VBSE financial comprehensive training, VBSE comprehensive practical training, graduation internship, and graduation design are performed.

\section{Implementation of accounting major education and teaching}

\subsection{Integrate innovative and entrepreneurial elements into the core curricula, and highlight innovation ability training in the practical curricula}

The National Standards for Teaching Quality of the Ministry of Education define that eight courses such as Fundamentals of Accounting are the core curricula of accounting majors and the main elements of entrepreneurship education. These courses are all based on the background of industrial enterprises, and implement accounting education of integrating specialty and innovation. The theme of innovation and entrepreneurship education can be integrated into the core courses, highlighting the professionalism, application, and the training goals of innovative thinking. Each curriculum can add chapters to introduce operation and management activities of science and technology innovation-oriented enterprise and small microservice enterprises, and conduct case analysis and discussion. Focusing on the cultivation of innovative spirit and innovative ability, employment and entrepreneurship training and practice closely related to professional development should be enriched to improve the system of innovation and entrepreneurship education.

\subsection{Innovate the teaching method of accounting specialized curricula}

It should accelerate the informatization construction of high-quality courses in accounting education, launch online open courses such as MOOC and video open classes, establish a system for learning certification and credit recognition of open online courses, and open practice teaching platforms to share educational resources. Besides, it can try to set up experimental classes, carry out school-enterprise cooperation and collaborative education, and improve the practice base of off-campus innovation and entrepreneurship for college students. Elective courses are added to develop a knowledge system for students with innovative and entrepreneurial interests. Students can carry out social practice in summer and winter vocation and research on small and medium-sized enterprises, and actively participate in college students' innovation and entrepreneurship contests, accounting skills competitions, and business plan competitions, to increase the practice of innovation and entrepreneurship and improve their innovation and entrepreneurial skills. 


\subsection{Develop distinctive model courses integrating specialty and innovation}

It needs to actively optimize the curriculum system of accounting major, select 1-2 courses in the core courses to fully explore the innovation and entrepreneurship education resources of accounting courses, develop distinctive model courses integrating specialty and innovation, organically integrate professional knowledge teaching with the innovation and entrepreneurship training, and enhance students' professional competence and comprehensive ability, to lay a solid foundation for students to engage in professional innovation and entrepreneurial activities. The development of the model courses can be combined with the construction of application-oriented curriculum system, and identify the theme of innovation and entrepreneurship education in the specialized courses, starting from the syllabus, teaching materials, teaching plans, practical teaching, assessment and evaluation. At the same time, it should strengthen the training of teachers' awareness and ability of innovation and entrepreneurship education, establish a curriculum group composed of full-time teachers and industry mentors, build a system for relevant professional teachers to take temporary posts in enterprises, and encourage teachers to lead students to practice innovation and entrepreneurship.

\section{Conclusions}

Integration of specialty and innovation is an important task to deepen the reform of innovation and entrepreneurship education. In the process of professional education, the existence of the innovation spirit of entrepreneurship education reform grasp enough, not enough emphasis, innovation entrepreneurship education idea lag, combined with professional education is not tight, course system, teachers' ability is limited, single way of education, and entrepreneurship practice, the effectiveness is not strong, the practice teaching platform construction lag and so on. The curricula are the basic carriers of innovation and entrepreneurship education. The close integration of innovation and entrepreneurship education and specialized education should be combined with the school-running orientation and the training objectives of accounting major, to build the curriculum system integrating specialty and innovation and put it into innovation practice. Adhere to the ability of the first, according to the characteristics of the professional, set up a variety of types of professional training, innovation training, practice activities, cultivate students' innovative spirit and innovative ability; Enrich employment and entrepreneurship training activities closely related to professional training and improve the employment and entrepreneurship training system. At the same time, it should improve teachers' awareness and ability of innovation and entrepreneurship education, deepen the reform of teaching methods, construct the system of teaching evaluation and quality supervision, integrate production and education, and deepen the reform of innovation and entrepreneurship education.

\section{Acknowledgement}

This project is one of the achievements of the teaching research and reform of Xi'an University, and the project number is JY2019JGA27.

\section{References}

[1] Yang Feng, Yang Xinjuan, Wang Yanhua. The educational theory and practice of integrating specialty and innovation: based on the perspective of comprehensive talent cultivation[J]. Journal of HigherEducation,2017(16):41-43.

[2] Lai Shaocong. Innovative education and teaching theory to improve the quality of talent cultivation[J]. China University Teaching, 2016(03): 27-31.

[3] Xuan Cuixian, Chen Hairong, Wang Chengfu, Zhang Yanping. Exploring the talent cultivation model of "Study, Research, Innovation and Application" in higher vocational colleges from the 
perspective of integrating specialty and innovation [J]. Heilongjiang Researches on Higher Education, 2019(6): 80-83.

[4] Huang Yao. Research on the National Standard of America Entrepreneurship Education [D]. Hunan Normal University,2017.

[5] Xie Liangan. Discussion on the Training System of Accounting Talents with Innovation, Entrepreneurship Education and Professional Education [J]. Education Teaching Forum, 2018(7): 29-30. 